\title{
'If I Had My House, I'd Feel Free': Housing and the (Re)Productions of Citizenship in Cape Town, South Africa
}

\author{
Marianne Millstein ${ }^{1}$
}

Published online: 29 July 2020

(C) The Author(s) 2020

\begin{abstract}
While urban divisions are commonly emphasized in urban studies, there has been less emphasis on reproductions and contestations of divides within marginal urban spaces. This paper explores the dynamics of juxtaposed differences related to housing and urban citizenship in Delft, Cape Town. Delft is a microcosm of thirty years of official housing interventions in post-apartheid South Africa. It is also a space in which differences of urban formality and informality and of permanence and temporariness co-exist, and where housing is at the centre of community politics. This is driven by residents' perceptions, interpretations and negotiations of differentiated housing rights and opportunities, residential categories and identities and notions of belonging. A particular manifestation of juxtaposed material and temporal differences in housing infrastructure is the construction of temporary relocation areas (TRAs). The multifaceted challenges with the TRAs in Delft illustrate the political nature of housing infrastructure as reported by (Lemanski 2019a, b) and how citizen-making is shaped in and through articulations of formality and informality, and of permanence and temporariness. This informs a politics of citizenship where the precariousness of permanent temporariness as reported by (Yiftachel 2009) for those living in the TRAs is set against those whose right to secure housing is realized, giving them recognition and permanence as 'proper' citizens. These dynamics may simultaneously inform rights-based claims to citizenship through collective struggles and individual actions, and localized forms of exclusion from the project of citizenship.
\end{abstract}

Keywords Cape Town · Infrastructure $\cdot$ Housing $\cdot$ Temporary relocations · Urban citizenship

Marianne Millstein

marmi@oslomet.no

1 Norwegian Institute for Urban and Regional Research (NIBR), Oslo Metropolitan University, Oslo, Norway 


\section{Introduction}

This paper explores the dynamics between juxtaposed material and temporal differences of housing and how these inform urban citizenship within Delft, a poor urban community in Cape Town, South Africa. While urban divisions are commonly emphasized in urban studies, there has been less emphasis on their reproduction and contestation within marginal urban spaces (but see Lemanski 2009; de Satgé and Watson 2018; Cirolia and Scheba 2019). This special issue uses the term juxtacity as an entry point to explore the dynamic qualities of such juxtaposed differences in urban spaces and what these produce. A critical question is what happens to perceptions and expressions of urban citizenship in places like Delft, where conflicting rationalities of the formal and planned intersect with the informal and unplanned (de Satgé and Watson 2018), and where spaces of formality and informality, and of permanence and temporariness rub up against each other.

Delft is a township built through greenfield ${ }^{1}$ low-cost housing development at the outskirts of Cape Town. While mainly a formally planned township, it also includes pockets of informal housing such as backyard dwellings and informal settlements, and state-constructed temporary relocation areas (TRAs) for emergency and relocation purposes. Perceived as a dormitory town and sometimes referred to as a dumping ground for the urban poor, Delft epitomizes how sociospatial segregation has been reproduced in the post-apartheid era, leaving the urban poor at the periphery of a deeply divided city (Millstein 2008). At the same time, Delft is also a dynamic and continuously changing community, where the co-existence of formal, informal, permanent and temporary housing has been at the centre of citizenship struggles.

The sociotechnical and political role of urban infrastructure and the multiple ways in which infrastructure connects and divides urban space is a well-established topic in urban studies (Graham and Marvin 2001; Amin 2014; Graham and McFarlane 2015; Amin and Cirolia 2018; Lemanski 2019a, b). This paper combines the juxtacity framework with writings on the political nature of infrastructure and relations between infrastructure and citizenship (Wafer 2012; Graham and McFarlane 2015; Amin and Cirolia 2018; Lemanski 2018, 2019b). Lemanski (2018:356) argues that the postapartheid state has pushed forward an 'infrastructural-centric vision of citizenship'. At the same time, housing and services have been at the centre of community politics, through which local social relations, identities and belonging also shape what it means to be seen and act as urban citizens. Infrastructure in the post-apartheid city is thus not only material, but deeply political and imbricated with democratic politics and citizenship (Amin and Cirolia 2018; Lemanski 2019a, b). Exploring this politics in Delft reveals how multiple formulations of urban citizenship may emerge and are entangled in complex and sometimes conflicting ways (Millstein 2017).

Housing offers a critical lens through which to understand changing state-society relations and the politics of citizenship in post-apartheid South Africa (Lemanski 2018, 2019a, b). Housing is a constitutional right (Republic of South Africa 1996), and

\footnotetext{
${ }^{1}$ Greenfield development are projects built on empty land often at the outskirts of the city where large pieces of land are available. This is in contrast to transformation of built areas no longer in use like industrial areas, and so-called in-fill projects where pockets of land in-between existing built environments are used for housing
} 
became central to the post-apartheid government's project of national transformation. It is thus intrinsically linked to questions of democratization and how to make formal rights a reality for millions of people who were previously excluded from such rights (Jones and Stokke 2005). However, the realization of housing rights has proved difficult. What the right to adequate housing entails is not straight forward, and national and local housing policies have shifted significantly since 1994, partially in response to extensive litigation of housing rights (Tissington 2011; Dugard et al. 2016; Cirolia et al. 2017). Thus, what the state has actually delivered has shifted over time. Although emphasis on formalization through homeownership seems to continue to be the ideal objective, an important policy shift from 2004 is that from the delivery of a top structure - i.e. a finished and serviced house - towards that of providing a range of housing opportunities including serviced sites and temporary shelter with some available services. But the delivery of a top structure is still the main delivery model, which in turn also shapes what residents perceive the right to housing to be. ${ }^{2}$

Although the state has delivered more than three million low-cost housing units since 1994, demand continues to outrun supply. In Cape Town, approximately 400,000 residents waiting for housing are registered in the City's housing database - often referred to as the waiting list - a requirement for accessing the housing opportunities it provides (City of Cape Town 2018). Housing and services have thus been key rallying points for social movements and community groups and continue to be a contested terrain. Some of the grievances have been the slow pace of delivery, limited participation in delivery processes as well as challenges with elite capture and patronage in participatory processes, lack of low-cost housing in inner-city areas, the poor quality of housing materials, the quality and affordability of public services, allocation of housing and associated demands for spatial justice, and the use, quality and peripheral location of temporary relocation housing that often turns permanent for those relocated. As I elaborate below, urban citizenship is thus differentiated and partial for those whose house - and other constitutional rights - is yet to materialize (Dugard et al. 2016; Levenson 2017, 2018; Lemanski 2019b; Wafer 2020).

The policy shift and challenges with housing delivery noted above, manifest in Delft in different ways. Various types of housing are present: state-built formal houses of different size and quality, informal backyard structures and small temporary units built in separate areas adjacent to Delft proper. It is a place where many have had their housing rights at least partially realized, even if the material quality and peripheral location have been disputed. But it is also a place where many residents are living in informal and temporary situations and are waiting and hoping to become homeowners through state-delivered permanent housing. These juxtaposed material and temporal differences in housing are a lens through which to explore multiple articulations of urban citizenship, and their entanglements, contestations and (re)productions.

The paper builds upon continuous engagements with and research in Cape Town and Delft, starting with my doctoral work (2004-2008) followed by a research project

\footnotetext{
${ }^{2}$ In this paper, I discuss the perceptions of what it means to become a homeowner and how this relates to materialities and temporalities of housing and to citizenship. It is important to note that receiving a house does not always mean that rights are fully realized in practice. Homeownership, rights and tenure security are complex issues in South African cities so that even for those receiving public housing, their tenure security might be undermined by backlogs in title deed transfers and other challenges in managing land and property (see Hornby et al. 2017, Shisaka Development Management Services 2011).
} 
on the politics of the TRAs (2012-2015). In both projects, I combined shorter and longer field visits conducting observations, interviews and focus group discussions with residents and activists, and interviews with City of Cape Town officials and politicians. My long-term engagement with residents and community activists provides a nuanced understanding of imbrications of cooperation and contestation that underpin a local politics of urban citizenship. The paper also includes some updated developments in the community, which build upon recent research, media reports and grey literature.

The remainder of the paper is structured as follows: I first elaborate upon the theoretical perspectives, where I link the juxtacity framework with recent work on infrastructure and citizenship. I then provide a narrative of the shifting housing policies and infrastructure in Delft, and how this reflects differentiated citizenship. I then turn to a discussion of some of the juxtaposed material and spatial differences of the TRAs in Delft. The contestations around the TRAs illustrate the political nature of public housing and how citizenship is shaped in and through the distinctive and juxtaposed materialities of informal, formal, temporary and permanent housing. In the conclusion, I summarize key observations and arguments on how juxtaposed differences of housing inform urban citizenship.

\section{Urban Divides, Juxtaposed Differences and Citizenship}

The interest in urban divides in this special issue is not a concern with dichotomies per se. Rather, it emphasizes the productive articulations 'between differences within the urban' (Hammar and Millstein 2019:3). The argument is that there is much to learn from exploring the productive frictions of multiple divides that characterize Southern cities (Simone and Pieterse 2017; Hammar and Millstein 2019). The juxtacity framework thus offers 'a relational lens with which to examine the dynamic articulation between forms, processes and practices of urban divisions on the one hand, and the production of and contestations over urban authority and citizenship on the other' (Hammar and Millstein 2019:1).

This paper is focused on how the articulations between and tensions within urban divides affect the (re)productions of urban citizenship. Citizenship is both a structuring and empowering concept (Holston 2009, 2011; Roy 2009). It is a legal term that structures and institutionalizes relations between states and residents, but is also a basis through which residents perceive themselves as part of a community, and/or can make claims based on rights and belonging (Miraftab and Wills 2005; Robins et al. 2008; Holston 2009; Staeheli et al. 2012). Urban citizenship is generally used to include everybody who lives in the city regardless of their legal status in relation to the state. In critical urban studies and associated fields, it is mostly linked to a Lefebvrian notion of the right to be in and produce the city (Brenner et al. 2012), where urban citizenship is claimed through self-construction and collective organizing (Holston 2008, Holston 2009). At the same time, the urban poor also evoke constitutional rights in their claims to the city, and that what emerges is an entanglement of multiple formulations of urban citizenship that are embedded in and play out in and through the 'residential domain of social life' (Holston 2011:336) in the urban peripheries (Holston 2009, 2011). In this literature, urban citizenship is often conceptualized through its collective and/or 
participatory dimensions. However, citizenship is not just expressed as rights-based claims through participation, collective action and protests, but also as mundane acts and practices. The latter means that we need to consider the importance of place (de Satgé and Watson 2018), the role of identity and belonging that inform multiple subjectpositions, and under what conditions and circumstances these may inform agency and practices in the everyday (Millstein 2017). Examining urban divides as productive spaces provides insights into how these complex dynamics and entanglements inform how residents are defined as citizens, but also how they contest and claim urban citizenship in multiple ways. Housing as a constitutional right as well as a key aspect of the 'residential domain of social life' is a key issue through which to explore such dynamics.

Literature on the political nature of material and infrastructural citizenship adds an interesting analytical lens to the juxtacity framework. Following Lemanski (2019a: 4),

infrastructure is conceptualized as the material objects and the social relations that create the lived environment; while citizenship is defined as the relationships (rights and responsibilities) and expectations between the state and citizens that manifest in legal rules, everyday acts and radical practices.

Neither infrastructure nor citizenship are new concepts in debates about Southern cities (for a summary, see Lemanski 2019a). Put simply, urban infrastructures are what make the city work, and failures to provide critical infrastructure are seen as key failures of governance. Urban residents' lives are shaped and mediated by how they are able to access and make use of such infrastructure (Graham and McFarlane 2015). Yet, according to Lemanski (2019a, 2019b), debates about infrastructure have rarely been linked to the language of citizenship. Similar to the arguments about the importance of ordinary or mundane practices of citizenship, she links this blind-spot to the tendency to focus on the politicized nature of infrastructure, where protests are seen 'as the primary representation of citizenship (e.g. Holston 2008; Brown 2015; Von Schnitzler 2016), thereby overlooking long-term everyday infrastructure practices and expectations through which state-society develop.' (Lemanski 2019a: 2). The politics of citizenship emerging from the juxtaposed differences of materialities and temporalities of housing include the whole spectre of collective and individual strategies and practices.

\section{Housing and Infrastructural Citizenship in South Africa}

In South Africa, the delivery of and access to municipal services have been at the centre of community protests (Ballard et al. 2006; Hart 2014; Brown 2015) reflecting the intimate relationship between infrastructure and citizenship in post-apartheid cities (Wafer 2020). Amin and Cirolia (2018: 289) argue that while not always expressed as being about the political or citizenship, 'there is a distinctive sense that infrastructures are political, their configurations decisive in the experience of urban citizenship and the evolution of the social contract.' Lemanski $(2018,2019 \mathrm{a})$ argues that in the South African context, it is useful to include housing as public infrastructure, given the 
central role of the state in housing delivery where the dominant model has been to deliver housing and full public services and where many of the grievances and community struggles linked to housing have been struggles against evictions, access to water and electricity, and so forth (Wafer 2012; Lemanski 2019a). The centrality of housing and associated services to the South African project of citizenship and a 'fixation with "formalization"...in terms of dwellings' (Cirolia et al. 2017:52) mean that the house and becoming a homeowner are reified as symbols of becoming a citizen. As Lemanski argues, the house becomes 'the material embodiment of a political identity' (Lemanski 2019a:6). However, what the material house embodies is not only a recognition as citizens of the state, but is imbricated with identities of place and notions of belonging. Hence, this is not only about inclusion in the national project of identity formation. The political nature of infrastructure is also important in local politics of identity. As Rodgers (2019) points out,

Access to urban services is, for example, often a hallmark of belonging to a particular group or polity, and can therefore become an issue around which conflicts about belonging can be articulated.

Infrastructure may thus be complicit in the (re)production of divisions within urban space as well as in their contestation and transformation. Housing and services provide a lens through which to analyse state-society dynamics in post-apartheid South Africa where the delivery and contestation over housing and public infrastructure is at the heart of both top-down and bottom up projects of citizenship. Housing policies defining how housing rights are to be realized, intersect with and are negotiated in particular social and political contexts and shape how housing rights are perceived and claimed in a particular place. These entanglements, negotiations and articulations inform local perceptions and experiences of what it means to be a citizen in relation to the state, but also in relation to other residents and groups of residents whose rights to resources are sometimes questioned and contested (Millstein 2014, 2017). An everyday lens on these dynamics shifts attention to how political subjectivities and agency may be produced and practiced through entanglements of policy categories and social identities, in ways that can be simultaneously disciplining and empowering of urban citizenship (Millstein 2017:255).

I now turn to Delft and start with a 'walk' through the various neighbourhoods to make visible the shifting housing policies in post-apartheid Cape Town, and how these are perceived and experienced. While not a comprehensive analysis of housing policies and governance, nor an exhaustive narrative of housing history in Delft, the aim is to reveal how shifting housing policies have materialized over time and how citizenship is differentiated as a result. This analysis also sets the stage for the following section which explores some of the tensions around the TRAs. Taken together, the analyses unpack how and why material and temporal differences in housing are key to understanding the dynamics of urban citizenship both in relation to the state and to placebased notions of identity and belonging.

\section{Housing and Urban Citizenship in Delft}

Located ca $30 \mathrm{~km}$ outside the central business district (CBD) of Cape Town and adjacent to the international airport, Delft is a microcosm of three decades of state- 
led housing development for the urban poor. As these policies have evolved, so has the delivery of housing in the community in terms of size, quality and materials. Housing delivery has provided for thousands of previously excluded residents, who now own their homes. But Delft also illustrates the unevenness of housing rights, and how citizenship is only partially realized for those who are still waiting for housing. Within and around the large areas of state-delivered houses, there are pockets of informality, mainly backyard dwellers (backyarders) living in informal structures in the backyards of formal houses. Additionally, Delft is a site where the state has constructed several TRAs into which residents are relocated temporary due to evictions and in response to other emergencies (DoHS 2009a). TRAs are also used as an intermediate solution when informal settlements elsewhere are targeted for upgrading or relocation (DoHS 2009b). TRA residents may thus originally have been homeowners, tenants, backyarders, informal settlement dwellers or homeless, and many have moved between different housing situations. Now, they find themselves in a different category, that of being temporary residents of a state-governed area where they are living in-between formality and informality, temporary in theory but permanent in practice, what Yiftachel (2009) has termed a state of permanent temporariness. I return to this in the following.

Map 1 visualises the various neighbourhoods in Delft that have been built in different phases since 1995. ${ }^{3}$ Most of the housing development in Delft has been built to accommodate the urban poor who qualify for a full subsidy under the national housing policies. In the 1990s, this subsidy scheme was used in greenfield projects, rolling out small units on a single free-standing plot. Delft was one of the first national large-scale developments of this period, and is often referred to as example of some of the failures of the early post-apartheid housing policies. A shift in policies in 2004 acknowledged the unsustainability of the previous programme, which had led to urban sprawl, bad quality houses at the fringes of the city and community fragmentation (Cirolia et al. 2017; Millstein 2008). This new Breaking New Ground (BNG) Policy sets out a more holistic and integrated approach to human settlements, providing a broader range of housing opportunities while also tackling sociospatial segregation. In addition to a continued focus on formal housing construction through the subsidy mechanism, the policy included two new tools with implications for Delft: The Upgrading of Informal Settlements Programme (UISP) which emphasized in situ upgrading in contrast to relocation to formal housing elsewhere, and the Emergency Housing Programme (EHP) used to provide alternative accommodation in the case of emergencies including evictions (DoHS 2009a, b; see Cirolia et al. 2017 for an overview of shifting policies in South Africa).

What the state has delivered and how has thus shifted since the first areas of Delft were constructed in the late 1980s, which manifest in different size and material quality in distinct neighbourhoods in the community. The houses built in the northern parts of Delft in the late apartheid years were historically rental units, in contrast to the postapartheid housing policy's emphasis on homeownership. The small and bad quality RDP (Reconstruction and Development Programme) houses of the early democratic transition in the 1990s make up Delft South, and were built through a nationally funded and provincially led project called the Integrated Serviced Land Project (ISLP). These

\footnotetext{
${ }^{3}$ The map was made for my $\mathrm{PhD}$ published in 2008, and does not include the TRAs built after 2005. The ward boundaries are not updated after the latest re-demarcations in Cape Town.
} 


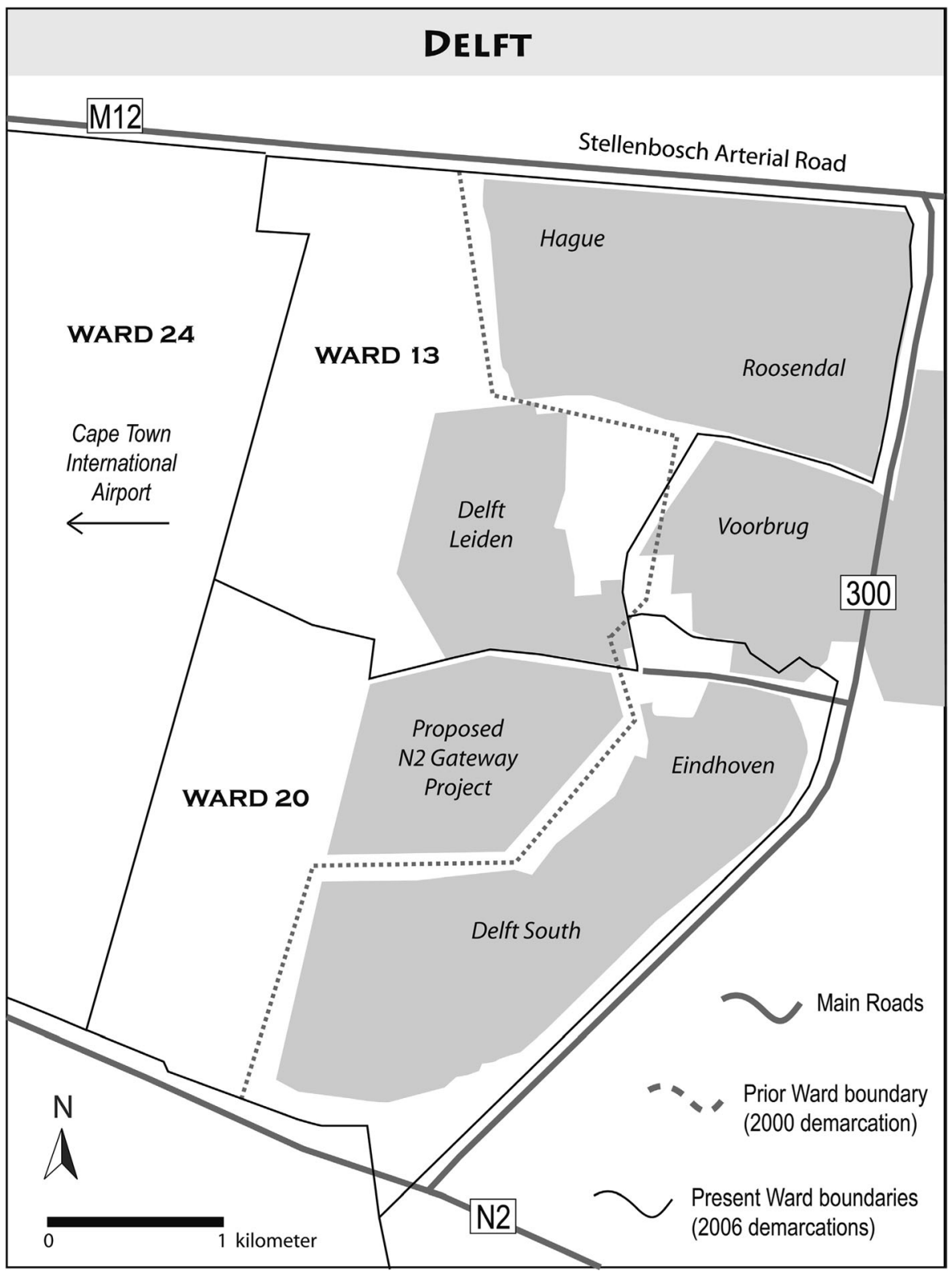

early housing projects had to accommodate both those living in informal settlementsat the time mainly black South Africans who had limited rights in the apartheid cityand those living in backyard shacks or overcrowded conditions in coloured townships. During the late years of apartheid, those living in these latter areas could register their housing needs with the City. The ISLP had a housing allocation policy in which houses were allocated on a 50-50 basis to those on the City's list and informal settlements, reflecting an overlap between apartheid racial identities and residential categories. While no longer a clear-cut reality - if it ever was - this legacy continues to shape a 
contested politics over housing through which apartheid-constructed racial identities intersect with residential categories and notions of insiders and outsiders/newcomers (Jacobs 2018; Millstein 2017; Millstein 2008).

The first RDP houses built in Delft were small and sub-quality standard. These houses were seen as 'starter houses', but community activists challenged the size and quality from the beginning. Some of the houses are still referred to as 'the asbestos houses', and community activists have tried for years to get the state to rectify the units. While some have extended and upgraded their houses themselves, many continue to live in the original structure. Some of these residents now described their houses as being similar to shacks and the temporary structures of the TRAs. One woman argued that her house was more temporary than permanent, and that residents in these houses should also have a right to a better house like the ones that were being built in more recent developments. A TRA resident who had been part of a group trying to mobilize residents both in Delft South and in the TRAs, said that

...asbestos was in the time of Mandela. But they should have known they can't put people in asbestos, it is a health problem at the end of the day. So I feel that South Africa didn't build descent houses before. ... It is time for SA to build decent houses for their people. With a geyser, with a shower, whatever they have, a bath, give the people nice.

Blikkiesdorp TRA resident, March 2013

However, since one can only receive a state housing subsidy once, Delft residents who received the early RDP houses will not have a second chance. The emphasis on tenure and ownership in these early policies were based on an assumption that houses could be improved and extended and thus also be financial resource. However, such value is yet to materialize for most residents, leaving them with limited chances of upward mobility (Lemanski 2011).

In contrast to Delft South, the neighbourhood called Delft Leiden is a mix of houses, with rows of semi-detached and two-storey units that differ from the 'one house- one plot' philosophy of the first construction phases. When these houses were built from around the year 2000, housing projects had moved from the notion of a starter house, to the roll-out of finished houses of minimum $30 \mathrm{~m}^{2}$. This reflects an increase in the subsidy available, and stricter quality specifications for what was to be delivered (Cirolia et al. 2017). While the material quality was better, the new structures made it difficult to informally extend the unit over time in response to household needs, as many had done with their free-standing RDP houses. The state continued to allocate these houses based on a combination of residents in informal settlements elsewhere and those registered on the City of Cape Town's waiting list from various communities in the city. However, at this time, there was increasing frustration with the way that new housing was being allocated. As I discuss in the following, tensions arose due to the changing responsibilities between state levels, alongside new policy tools and efforts to standardize criteria for eligibility while at the same time taking local conditions and needs into consideration.

Following the shift in housing policies in 2004 (Breaking New Ground - BNG), Delft became one of the most important sites for a BNG national pilot project called the 
N2 Gateway project. The project targeted informal settlements along the N2 highway linking the airport and the city centre. The BNG polices and the N2 Gateway emphasized in situ upgrading of informal settlements. In practice, many informal settlement dwellers were to be allocated a house in Delft, which was one of few areas where land was still available for large-scale housing development. One argument for relocation was that even if in situ upgrading was to be done, existing levels of density in the original settlements would not be viable, and many would therefore have to be relocated elsewhere (Millstein 2008; see de Satgé and Watson for a case study of the challenges with urban planning and the N2 Gateway project). It is important to note that despite a rhetoric of incremental development, in situ upgrading remains limited in favour of the delivery of finished housing units (Cirolia et al. 2017). The N2 Gateway project was also criticized for legitimizing a continued emphasis on eradication and relocation rather than incremental upgrading of informal settlements (Huczhermeyer 2011). BNG is thus more a continuity of, rather than a break from previous delivery of RDP houses, although the size and quality has improved. The BNG houses in Delft are $42-\mathrm{m}^{2}$ brick houses, with some variances in types of houses.

While mostly made up of formal housing, Delft's neighbourhoods are increasingly characterized by different modes of informality (Cirolia and Scheba 2019). Many have extended their unit with informal structures. Over time, some houses have also been upgraded and extended in ways that give them a more 'formal' look as compared to the initial informal extensions (ibid.). Another feature of informality common in Delft is backyard dwellings. Backyard dwellings are informal shelters built in the backyard of the plot to house family and friends, or to rent out to earn an income. While not a new phenomenon, the increasing importance of this kind of informality is intrinsically linked to the roll-out of RDP/BNG housing (Lemanski 2009; Gardener and Rubin 2017). Gardener and Rubin (2017:78) argue that 'back yarding is a complex phenomenon that challenges the current approach to the binary of formality/informality in cities', which requires a different intervention than that of conventional informal settlement upgrading policies. This is increasingly acknowledged by state actors, and the City of Cape Town launched a backyarder initiative in 2014 to improve access to basic services, but new policy tools have yet to be developed to provide 'security of tenure for more vulnerable urban residents' (ibid: 79).

The above 'walk' through types of housing in Delft gives a snapshot of thirty years of state-led housing delivery in South African cities. As noted earlier, housing is a key entry point to understand the South African state's developmental project and changing state-society relations since 1994. Delft has been built through shifting national and local housing policies, capacities and concrete interventions. While recent policies emphasize a more diverse and holistic approach that include a variety of housing opportunities, Delft manifests the continued objective of turning temporary and informal residents into permanent and formal homeowners. This has put housing at the epicentre of community politics and organizing, centring on the material quality, location and allocation of opportunities (Millstein 2014, 2017; Amin and Cirolia 2018).

Citizenship implies both structuring and empowering relations. Beneficiary categories in housing policies and interventions inform perceptions and experiences of being seen as citizens, but also how citizens collectively and individually position themselves and negotiate access to such rights. Seen from the state, the progressive realization of housing rights is managed through the development of a range of policies and 
eligibility criteria to prioritize who is to be beneficiaries of limited state resources. Some might see these as means through which the state seeks to discipline residents through registrations, provisions to adhere to legal frameworks and wait for their turn in an increasingly complex regime of governmentality. Drawing upon Yiftachel's (2009) notion of grey spaces - spaces in-between formality and informality, of legality and illegality - Greyling and Oldfield (2015) describe the lack of clarity experienced by South African residents waiting in a state of permanent temporariness, including the multiple ways citizens strategize and act in order to access housing. Greyling and Oldfield argue that waiting is often taken for granted by policy-makers, ignoring how the act of waiting represents a substantial burden for the poor who must manoeuvre within a web of procedures and processes that include documentation requirements and formal registration. Some of the management tools used by the state are housing databases and waiting lists. While the provincial government is responsible for managing the database of applicants for housing subsidies, the City of Cape Town has a housing database of residents in need of housing. The City's database - referred to as the waiting list - plays a key role both as a governmental technology of control as well as an object of critique and contestation (CLC and SERI 2013; Levenson 2017, 2018). The City insists that its allocation of housing opportunities follows the waiting list and that anyone who believes they have a right to housing assistance must register. Thus,

Households living in informal settlements, backyard shacks and overcrowded housing put their name on opaque waiting lists with the hope of receiving a 'proper' house (Cirolia and Scheba 2019: 11).

One reason for why the waiting lists are opaque as Cirolia and Scheba put it is because the actual use in practice remains unclear and is subject to local conditions and defined needs. National criteria for being eligible vary somewhat with different housing policies. To qualify for a BNG house (full subsidy with top structure), one must have a household income of less than R3500, be married and/or have co-dependents and not have received support before. Locally, the City of Cape Town has added that up to $90 \%$ of beneficiaries must come from their database - the waiting list - selected according to the date they registered. The final $10 \%$ may not be registered and may come from informal settlements (often those close to a planned housing project), but they still need to qualify for a full subsidy according to national criteria and be registered on the subsidy housing database managed by the provincial department of human settlements (City of Cape Town 2009, 2018).

In practice, it is challenging to negotiate these criteria both for the various levels of the state and for the residents. As an official pointed out (interview, official 2 March 18, 2013), there is not a single area in Cape Town where they can build something without making some local requirements to the host or nearby community, even if this means that formal criteria may be modified/adjusted and residents longer on the waiting list will be by-passed. Furthermore, and important for the tensions between Delft residents living in different modes of informality, the policies and criteria allow for an area-based allocation linked to informal settlements, which is de-linked from allocation according to the individual registrations on the waiting list. A local official thus expressed a commonly held argument among housing officials and politicians: 
The informal settlers got an advantage over call it the backyarder right across the metro where you got a double chance if development should happen in your area where you live in the informal settlement then you immediately qualify if you meet the criteria, depending on what we plan to put there. ... if it is UISP, ${ }^{4}$ you still benefit because the city can't wish you away. Even if you don't qualify for a subsidy you still get a site with services.

Local official 2, March 182013

As the official refers to, within the national policies on upgrading informal settlements, UISP, it is possible to circumvent waiting lists and use an area-based criteria of residency, namely that of the actual informal settlement-normally based on a cutoff date to exclude possible 'newcomers' - to allocate some housing opportunities. While informal settlement dwellers still have to be eligible for a subsidy (depending on what is being built in the relevant housing project), they do not always have to be on the City waiting list. This was the case for the informal settlement dwellers who were identified as beneficiaries of the N2 Gateway houses in Delft. In another housing project in Delft initiated by the City and not linked to the N2 Gateway project, they also decided that a majority of the units would be allocated to residents from within the community or near-by areas, and also accommodate some of the Blikkiesdorp TRA residents, but beneficiaries had to fulfil both criteria: being registered on the City's waiting list and qualify for a full subsidy.

Thus, housing rights are not only differentiated over time in terms of shifts in what is being delivered, but how these rights are allocated also vary depending on which level of the state is leading the project, despite attempts to standardize allocation policies nationally and locally. At the time of fieldwork in 2013 and 2014, the provincial government and the parastatal organization HDA were in charge of ongoing N2 Gateway projects, while the City of Cape Town initiated a city-led in-fill project building subsidized housing, with separate project committees, separate allocation procedures and limited cooperation between them. Such differences in processes and in what was actually being delivered and how caused confusion and tensions in Delft, feeding existing notions of informal settlement dwellers as newcomers and outsiders who have gained rights at the expense of those in need within the community.

As a result of such local dynamics and articulations, there is no universal approach as to what the right to housing means and how it should be fulfilled, resulting in differentiated urban citizenship (Parnell 2008; Tissington 2011; Dugard et al. 2016). Residential categories attached to different kinds of informal living are historically embedded both in the apartheid legacy, and in the post-apartheid efforts to challenge them by making provisions for various groups. While this is critical in order to deal with legacies of sociospatial injustice, such categories also take upon a life of their own in local politics. Categories such as backyarders and informal settlement dwellers and eligibility criteria defining beneficiaries, qualifiers and non-qualifiers of state support as they are used in policies, not only structure and differentiate citizenship from above. Such categories seep into local politics of housing rights, sometimes setting

\footnotetext{
${ }^{4}$ Projects that are initiated under the Upgrading of Informal Settlement Policies (UISP) have different criteria and are exempt from the City's general allocation policy.
} 
marginalized groups against each other over access to scarce resources (Millstein 2017). While many have become homeowners, informality has followed formal development so that a substantial number of Delft residents are renting informal housing in other people's backyards. At the time when the N2 Gateway project was launched in 2005, backyarders' housing needs became deeply politicized both through community activists as well as some local politicians. While not seen as outsiders to the community, backyarders lacked the security of tenure that ideally should come with homeownership, and many struggled with affordability and access to services depending on the good-will of the landlord. Backyarders thus perceived themselves to be ignored by the authorities, and despite having waited patiently as had been expected of them by the state, they were unjustly by-passed when new housing was delivered. Instead, in their view, the state gave preferential treatment to informal settlement dwellers who had come to the city more recently ${ }^{5}$ and had not waited their turn.

\section{Formal, Yet Informal, Temporary Yet Permanent: Temporary Relocation Areas}

Temporary relocation areas are products of some of the developments described above, and are themselves manifestations of juxtaposed material and temporal differences in housing and services. Delft was one of the first communities where the state built TRAs in the post-apartheid era. The provision to use temporary relocation in emergencies is found in the Emergency Housing Policy (EHP), which originated in a key constitutional court case (the Grootbroom case of 2000) and was developed as part of the BNG policy shift (DoHS 2009a). The first TRA, nicknamed Tsunami, was constructed in 2005 when a fire in Joe Slovo informal settlement left around 12,000 people homeless. Joe Slovo was located adjacent the N2 highway close to a township named Langa closer to the city centre than Delft. While some of the fire victims were provided emergency housing close-by, many of those who lost their homes were moved to Tsunami TRA in Delft and registered as beneficiaries of the N2 Gateway project. While the City provided the land, the TRA was constructed and managed by the N2 Gateway project. As a national pilot managed at a provincial level, the City had only a limited role and influence in the project (Millstein 2011).

Just across the Symphony Way road from Tsunami is the Symphony Way TRA, infamously known as Blikkiesdorp. This TRA was built by the City of Cape Town to accommodate a group of residents who had invaded and subsequently been evicted from N2 Gateway houses in Delft. Most of the residents who participated in the invasion were backyard dwellers from Delft or surrounding communities. As one of the participants explained,

you see, the main thing is that most of the people didn't have their own houses, so that is what made us go take the houses of the state like that (Blikkiesdorp TRA resident 13, March 25, 2013)

\footnotetext{
${ }^{5}$ Some have pointed to the fallacies of these perceptions. For instance, Levenson $(2017,2018)$ argues that internal mobility is an important factor driving land invasions.
} 
The residents who invaded the houses were evicted by court order in 2007, and moved onto live provisionally in tents on the Symphony Way, which made this an issue for the City of Cape Town to resolve. Their solution, and in accordance with the national EHP Policy, was to construct an emergency TRA, and the first residents were relocated to Blikkiesdorp in 2008. A group linked to the Western Cape Anti-Eviction Campaign resisted the initial relocation, demanding that the City provided them permanent houses. They managed to stay on the street for two years until they were eventually relocated to Blikkiesdorp.

As noted earlier, how policies define and categorize specific interventions and beneficiaries frame local responses in different ways. One example of such dynamics is the categorical distinctions between informal settlements and the TRAs. While the TRAs are constructed by the state and thus formal in some sense, they are perceived to be informal not just because it is supposed to be temporary but also in the use of materials and substandard services. As one official described it, TRAs such as Blikkiesdorp and Tsunami were more informal than formal, or as he put it, 'formalinformal' (official 3, March 222,013). In 2013, some activists in Blikkiesdorp had started to refer to the TRA as an informal settlement. When I asked a local official about this debate, he answered that:

No it is a TRA. They do that distinction because... an informal settlement, if they were an informal settlement they would have qualified for a percentage of the people there to be given a house in the project. So it is not an informal settlement. They wanted to be an informal settlement so that more people can benefit because they say now we'll take 200 people from the Blikkiesdorp informal settlement that is on the database to give them a house (local official 9, March 27 2013).

If the area was defined as an informal settlement and not a TRA, they could be eligible for projects framed by the UISP policies. Potentially, this could provide alternative interventions to an undefined future relocation elsewhere, including a more area-based approach that (in theory) could accommodate Blikkiesdorp residents collectively to a near-by project, rather than relying on individual allocation according to the City waiting list. These differences in policies and subsequently what options were available — perceived or real—-fed into tensions between the two TRAs, despite their shared experiences of living temporary in substandard housing with limited access to services.

On one of my fieldwork days in 2013, I drove through the intersection separating the two TRAs. The traffic lights were destroyed and something had been burning in the street. I asked my informants what had happened:

NN told me about the robot [intersection]. They had gone to bed early and woke after hearing some noise and saw people from Tsunami burning tires [in the street]. They didn't really know why, but some of the other residents had said it was related to their situation [living conditions]. Apparently they are now also demanding housing from the [housing] project - not just the N2 Gateway, but the City project [in-fill project]. So then rumours had started in Blikkiesdorp that if Tsunami got houses, then they would be excluded, which, according to 
[community leader] is not true. So now there are tensions building. She (NN2) said that the day before, the Tsunami residents had toyi-toyied again and had caused the black-out, which led to an out-cry of anger among other participants [from Blikkiesdorp] over why they [Tsunami residents] have to make life difficult for them, why should they complain when many of them did get houses while people living in Delft for years did not get houses.

Field notes, March 21, 2013

In interviews with other residents in Blikkiesdorp, Tsunami was referred to as a dangerous no-go area. The frustration over not knowing what would happen with their own housing situation was also set against what they perceived was going on across the street:

Now you get people that is not even on the waiting list, and they get houses. Because we had that problem there over the road [Tsunami]. Those people don't even know about the housing list but they are in houses now, so I ask myself: how did they get there? How did they get to be a homeowner?

Blikkiesdorp TRA resident 13, March 25, 2013

Their different origin and perceptions of belonging above, described is part of the explanation for these local perceptions and claims. Tsunami residents were relocated to Delft at a time when there was growing dissatisfaction over the fact that only a limited percentage of N2 Gateway project houses would be allocated to those living in the community. The invasion of N2 Gateway houses in 2007 and the subsequent construction of Blikkiesdorp TRA as an emergency response to house those being evicted was triggered by these tensions. In 2013, such sentiments continued to divide the two settlements, and recent reports suggest that it is still a source of contestation. In 2019, Groundup reported that Delft backyarders threatened to occupy open land because they 'were not given the same opportunities as people living in informal settlements' (Gontsana 2019).

The tensions between the TRAs were not only linked to their different origin, but to how authorities tried to govern different modes of material and temporary living that, in turn, informed different relations to the state and to what options that would be available in order to move from a temporary to a permanent housing situation. As noted earlier, the eligibility of Tsunami residents for N2 Gateway houses was linked to their residency in Joe Slovo regardless of the City's waiting list. Blikkiesdorp residents, in contrast, were relocated as an emergency response and their eligibility was more complex. The aim of the relocation was to 'get people off the road' (local official 2 March 182,013), and there was no consideration of eligibility prior to relocation. Thus, it was inevitable that once relocated, not all residents would qualify for future housing opportunities even if the relocation to the TRA was meant to be a temporary measure. Tsunami residents, then - at least the original group relocated in 2005 — would only have to be approved for subsidies and even if they did not qualify, they would be provided with some alternative through serviced sites or another temporary solution. In contrast, those residing in Blikkiesdorp, which is used for emergency housing run by the City, would have to both fulfil the criterion of qualifying for subsidy and be registered on the City's waiting list. 


\section{Past, Present, Future: the Dream of the Brick House}

I told myself where are we going to go now? Are we going to end up again as we lived before? I don't want to go back to how we lived before. ... And then the other panic was that if we were going to go out, we were going into another temporary settlement. I rather want something ... even a one room house, at least we can build a house and finish it ourselves as long as they say that this property is yours. We can make a plan to finish the house. But to live like this, where you don't know where you going to end up, that is very scary

Blikkiesdorp TRA resident 10, March 152013

In describing their everyday lives in a state of permanent temporariness, Blikkiesdorp TRA residents compared their situation with their previous housing situations, as well as with what a proper house would be once it would materialize. The house represents much more than a roof over one's head. Getting a house and becoming a homeowner solidifies the social contract with the state. It structures how they are seen - and see themselves - as citizens. And as several informants described, it was also about freedom and future economic security for their children. But for most TRA residents - and others living in other modes of informality and insecurity in the city - it was also about struggle, although not only through disruptions and protests. Not surprisingly, many TRA residents had a precarious housing history in the city, as backyard dwellers, evicted tenants, homeless or as in the case of Tsunami TRA, informal settlement dwellers. Many had been moving back and forth between such various conditions. A sense of insecurity continued and increased in the TRA, not least because of the lack of clear solutions in any near future. The high levels of violence and crime added to residents' sense of vulnerability, but there were also nuances in these narratives. Although uncertainties characterized the everyday, many also pointed out that the TRA at least gave some security of tenure and access to free services even if these were substandard. They did not have to pay rent to any landlord, and had electricity and water. Going back to where they had been was not an option.

While all perceived the TRA to be a temporary situation towards something else, there were different strategies and practices of how to deal with the present. Parallel to community organizing around grievances such as substandard services and the lack of plans for what would happen next, many residents also engaged city authorities in different ways to try to improve structures, seek out solutions and report illegalities such as illegal renting out of the TRA units. Some activists were allegedly negative towards residents trying to informally improve their structures, because it would symbolize a sense of permanence that could be detrimental to their struggle for achieving a permanent solution elsewhere. Officials, on their part, would not interfere even if such adjustments were formally a breach of the rental agreement, provided that it did not disrupt access roads etc.

For those waiting and yet to receive a housing opportunity, the dreamed-of house is linked to a particular form of materiality, namely the fully serviced brick house. The notion of a proper house being a brick house partially reflects the kind of housing that has been rolled out since 1994 - a free-standing brick house (as noted previously, some of the houses in Delft Leiden and other areas have used different models). When alternative materials were suggested for houses built in the latest phases of the N2 
Gateway project, residents objected and claimed that the quality resembled the temporary structures of the TRAs and did not constitute a proper house:

People were upset because when they looked at the material that was on site, and the material that is in TRA 5 it is look-a-like. Look, we are coming out there to get to the houses, not to a house that looks like a temporary house, it is not a permanent house. Because there is no brick there, it looks like ... I don't know what to call it, I just call it a temporary house. I'm not sure, because we know the houses built in N2 gateway from here to that side that is all houses they have built in bricks. But now we see that they are trying again to get another type of houses. Even if they will be going to do that, they are supposed to come to us, and then ask or show us the material so that we can see what's really happening and then we can discuss on that. If it is about building temporary houses we didn't mind, because people can be relocated there temporarily .... But if it is going to be that permanent house? So it is chaos for the people because they know what a house looks like. Tsunami TRA resident 16, March 252013

There is another project, it is not brick houses, almost like cardboard? Now .. I don't have anything against that, but how long is that house going to keep me? My house is supposed to be for life time it is not just supposed to be for an hour. Not to say I don't want it, it is just that how long is it going to last for? what I also want to know is whether it is brick house and whether it is that house - what is the value of it. Then I'm thinking the other house is not brick house that will last me a life time

Blikkiesdorp TRA resident 12, March 252013

For TRA residents, their sense of insecurity and precariousness was linked to the experience of waiting in the TRA but also to the material quality of their current units, which was set up against expectations of what kinds of materials that make a proper home. Receiving a house - and a particular type of house-becomes a signifier of being seen as a full citizen in the new South Africa (Lemanski 2018, 2019b). Those who are yet to become homeowners are left to wait for the state to be able to deliver upon their obligations, and/or to find ways to realize their housing rights through individual or collective strategies and actions.

\section{Conclusion: Becoming Proper(Tied) Citizens}

Housing and homeownership are central to the project of citizenship in South Africa both in state policies from above, and to the claims to and contestations over housing rights and what a proper house should be from below.

In the discussion, I have explored the juxtaposed differences of housing in Delft, and tried to unpack what these 'do' to what it means to be seen and act as urban citizens. In short, these juxtaposed differences are manifestations of state-driven differentiations of housing rights, but also themselves productive of local perceptions of and contestations over who has rights, who belongs, who is a citizen. A central notion running through these dynamics is a perception of the centrality of the house in order to be included in 
the project of urban citizenship. Delft has been built incrementally over time as a drive from the state to realize what Lemanski has termed an infrastructure-centred citizenship; one that has been framed by changing national housing policies, capacities and concrete interventions. These changes involve shifting responsibilities and tensions between various spheres of government and their roles in housing development. South Africa has developed an increasingly complex housing governance framework. Residents struggle to constructively engage complex policies and concrete interventions, and use multiple practices in their efforts to access housing and other state-provided resources. There are both continuities and changes in how state actors perceive what they are mandated to deliver and how they define citizens with rights and responsibilities. This is reflected in the different types of housing in Delft, and it also inform how residents' perceive and make claims to housing rights and see themselves as citizens.

Moving beyond seeing housing as the material manifestation of a political identity as a South African citizen, this paper shows how multiple differentiations and divisions within a particular space produce a local politics of urban citizenship that is simultaneously about how housing rights are differentially realized and claimed, and about place-based notions of identities and belonging. As Amin and Cirolia (2018:275) notes, 'struggles for adequate housing are deeply conflicted. This is particularly so when explored through the interwoven themes of state programmes/policy, social practices and material agency'. Residential categories such as homeowners, backyard dwellers, informal settlement dwellers and temporary residents have materialities and temporalities associated with them. Different kinds of informal living, such as informal settlement dwellers and backyarders, are historically embedded in the apartheid legacy of racial and class inequalities. The legacies of apartheid and the ways in which early postapartheid housing development in Cape Town were used as a tool for racial integration, mean that local politics is shaped by a fluid yet contested politics of racial identities (Millstein 2017). In the post-apartheid era, such categories have been codified into policies in order to identify existing needs and define possible opportunities. Although the aim is to overcome such historical divisions, and even if they are sometimes articulated in new ways and contested, policies are also implicit in their reproductions. While these categories are structured from above through state discourses and policies, they inform and are informed by the ways residents engage with or (re)interpret them, and strategically position themselves in order to access housing opportunities. Shifts in policies from delivering houses to housing opportunities, as well as complex eligibility criteria for different kinds of opportunities, thus articulate with existing positions and identities in a particular place, and inform fluid subject-positions linked to notions of belonging, of residential status, and of property.

Situating infrastructural citizenship in the everyday shifts attention to how such subject-positions are articulated and produced, and explores further how these may or may not inform multiple formulations, acts and practices of urban citizenship. Delft residents perceive, interpret and negotiate multiple, overlapping divides associated with housing rights and opportunities, different materialities of housing, ownership status, permanence and temporariness, and distinctions between informality and formality. Residential categories are not only technical descriptions used in housing policies to define and manage eligibility, differentiating citizenship as a result though state interventions. They also become signifiers of differences in urban citizenship in the everyday, of being more or less formal, more or less permanent or temporary, having more or 
less rights attached to them, and generating more or less belonging to the community. Tensions arose between the two adjacent TRAs partially because those settled in the Tsunami TRA, originally constructed by the state to house informal settlement dwellers from outside Delft, were perceived as newcomers/outsiders. Even though the occupants of the two TRA shared experiences of displacement and uncertainty, the right of socalled outsiders to housing opportunities in Delft was questioned by residents in Blikkiesdorp TRA, as well as by backyard dwellers in Delft.

Despite a rhetoric of accepting informality, there is a strong drive towards transforming residents from informal and temporary, to becoming formal and permanent homeowners. In these processes and subsequent negotiations and contestations, material and temporal differences of housing intersect with residents' perceptions of past, present and future. The dream of becoming a homeowner of the state-delivered brick house is set against previous experiences of precariousness, insecure tenure and deteriorating living conditions in informal housing. For those living in different modes of informality including those TRA residents whose future solution is yet to materialize, the precariousness and uncertainty that comes with waiting indefinitely for a housing solution is also set against those whose right to housing is realized, giving them recognition and permanence as 'proper(tied)' citizens (Hammar 2017). Moving from being informal and temporary to formal and permanent is about becoming recognized as 'proper' urban citizens, or, as the title of this paper suggests, to becoming free ${ }^{6}$.

Funding Information Open Access funding provided by OsloMet - Oslo Metropolitan University.

Open Access This article is licensed under a Creative Commons Attribution 4.0 International License, which permits use, sharing, adaptation, distribution and reproduction in any medium or format, as long as you give appropriate credit to the original author(s) and the source, provide a link to the Creative Commons licence, and indicate if changes were made. The images or other third party material in this article are included in the article's Creative Commons licence, unless indicated otherwise in a credit line to the material. If material is not included in the article's Creative Commons licence and your intended use is not permitted by statutory regulation or exceeds the permitted use, you will need to obtain permission directly from the copyright holder. To view a copy of this licence, visit http://creativecommons.org/licenses/by/4.0/.

\section{References}

Amin, A. (2014). Lively infrastructure. Theory, Culture and Society, 31(7-8), 137-161.

Amin, A., \& Cirolia, L. R. (2018). Politics/matter: governing Cape Town's informal settlements. Urban Studies, 55(2), 274-295.

Ballard, R., Habib, A., \& Valodia, I. (Eds.). (2006). Voices of protest: social movements in post-apartheid South Africa. Durban: University of KwaZulu-Natal Press.

Brenner, N., Marcuse, P., \& Mayer, M. (2012). Cities for people, not for profit: critical urban theory and the right to the City. London: Routledge.

Brown, J. (2015). South Africa's insurgent citizens: on dissent and the possibility of politics. Auckland Park, Johannesburg: Jacana Media.

Cirolia, L. R., \& Scheba, S. (2019). Towards a multi-scalar reading of informality in Delft, South Africa: weaving the 'everyday' with wider structural tracings. Urban Studies, 56(3), 594-611.

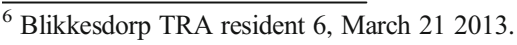


Cirolia, L. R., Görgens, T., van Donk, M., Smit, W., \& Drimie, S. (2017). Upgrading informal settlements in South Africa: an introduction. In L. R. Cirolia et al. (Eds.), Upgrading informal settlements in South Africa. A partnership-based approach (pp. 3-25). Cape Town: UCT Press.

City of Cape Town (2009/15). Allocation policy: housing opportunities (Policy no 11969). Originally approved August 2009, revised and approved 25 March 2015.

City of Cape Town (2018). Your guide to housing opportunities in Cape Town. Cape Town: City of Cape Town/Transport Development Agency (TDA). Downloaded February 282020.

CLC \& SERI. (2013). 'Jumping the queue', waiting lists and other myths: perceptions and practice around housing demand and allocation in South Africa. Community law centre, University of the Western Cape, Cape Town, and Socio-economic rights institute, Johannesburg.

Demand and Allocation in South Africa. (N.D.) Johannesburg: Community Law Centre, University of the Western Cape, and Socio-Economic Rights Institute of South Africa.

De Satgé, R., \& Watson, V. (2018). Urban planning in the global South: Conflicting rationalities in contested urban space. London: Palgrave Macmillan.

DoH. (2004). Breaking new ground: a comprehensive plan for the development of sustainable human settlements. Pretoria: Department of Housing.

DoHS. (2009a). The housing code: incremental interventions (part 3), emergency housing programme. Pretoria: Department of Human Settlements.

DoHS. (2009b). The housing code: incremental interventions (part 3), upgrading of informal settlement programme. Pretoria: Department of Human Settlements.

Dugard, J., Clark, M., Tissington, K., \& Wilson, S. (2016). The right to housing in South Africa. In Foundation for human rights (eds.), Socio-economic rights-progressive realization? Johannesburg: FHR.

Gardener, D., \& Rubin, M. (2017). The 'other half' of the backlog: (re)considering the role of back yarding in South Africa. In L. R. Cirolia et al. (Eds.), Upgrading informal settlements in South Africa. A partnershipbased approach (pp. 77-96). Cape Town: UCT Press.

Gontsana, M-A. (2019). We will occupy any open land, vow backyarders. GroundUp January 31, www. groundup.org.za/article/we-will-occupy-any-open-land-vow-backyarders/ downloaded August 142019.

Graham, S., \& Marvin, S. (2001). Splintering urbanism. Networked infrastructures, technological mobilities and the urban condition. London: Routledge.

Graham, S., \& McFarlane, C. (Eds.). (2015). Infrastructural lives. Urban infrastructure in context. Abingdon: Routledge.

Greyling, S., \& Oldfield, S. (2015). Waiting for the state: a politics of housing in South Africa. Environment and Planning A: Economy and Space, 47(5), 1100-1112.

Hammar, A. (2017). Urban displacement and resettlement in Zimbabwe: the paradoxes of propertied citizenship. African Studies Review, 60(3), 81-104.

Hammar, A \& Millstein, M. (2019). Juxtacities: urban divides, authority and citizenship in the global South. Paper presented at the workshop at the frontiers of the urban: thinking concepts \& practices globally. London, 10-12 November 2019.

Hart, G. (2014). Rethinking the South African crisis. Nationalism, populism, hegemony. Durban: University of KwaZulu-Natal Press.

Holston, J. (2008). Insurgent citizenship. Disjunctions of democracy and modernity in Brazil. Princeton (NJ): Princeton University Press.

Holston, J. (2009). Insurgent citizenship in an era of global urban peripheries. City \& Society, 21, 245-267.

Holston, J. (2011). Contesting privilege with right: the transformation of differentiated citizenship in Brazil. Citizenship Studies, 15, 335-352.

Hornby, D., Royston, L., Kingwill, R., \& Cousins, B. (2017). Introduction: tenure practices, concepts and theories in South Africa. In D. Hornby et al. (Eds.), Untitled: Securing Land Tenure in Urban and Rural South Africa. Durban: KwaZulu-Natal University Press.

Huczhermeyer, M. (2011). Cities with slums. From informal settlement eradication to a right to the city in Africa. Cape Town: UCT Press.

Jacobs, S. (2018). The limits of coloured nationalism. Op.ed. published in the Mail\&Guardian June 132018 , https://mg.co.za/article/2018-06-13-00-the-limits-of-coloured-nationalism/ downloaded August 142019.

Jones, P., \& Stokke, K. (Eds.). (2005). Democratising development: the politics of socio-economic rights in South Africa. Leiden: Martinus Nijhoff.

Lemanski, C. (2009). Augmented informality: South Africa's backyard dwellings as a by-product of formal housing policies. Habitat International, 33(4), 472-484.

Lemanski, C. (2011). Moving up the ladder or stuck on the bottom rung? Homeownership as a solution to poverty in South Africa. International Journal of Urban and Regional Research, 35(1), 57-77. 
Lemanski, C. (2018). Infrastructural citizenship: spaces of living in Cape Town, South Africa. Infrastructural citizenship: spaces of living in Cape Town, South Africa. In A. Jones, B. Miller, K. K. Ward, \& D. Wilson (Eds.), The Routledge Handbook on Spaces of Urban Politics (pp. 350-360). London: Routledge.

Lemanski, C. (2019a). Infrastructural citizenship: the everyday citizenships of adapting and/or destroying public infrastructure in Cape Town, South Africa. Transactions of the Institute of British geographers, published online 23th of Dec 2019, https://doi.org/10.1111/tran.12370

Lemanski (Ed.). (2019b). Citizenship and infrastructure. Practices and identities of citizens and the state. London: Routledge (Routledge Studies in Urbanism and the City).

Levenson, Z. (2017). Precarious welfare states: urban struggles over housing delivery in post-apartheid South Africa. International Sociology, 32(4), 474-492.

Levenson, Z. (2018). The road to TRAs is paved with good intentions: dispossession through delivery in postapartheid Cape Town. Urban Studies, 55(14), 3218-3233.

Millstein, M. (2008). Challenges to substantive democracy in post-apartheid Cape Town: the politics of urban governance transformations and community organising in Delft. $\mathrm{PhD}$ thesis, University of Oslo, the Faculty of Social Sciences, Department of Sociology and Human Geography. 354 p.

Millstein, M. (2011). Urban governance transformations and the first two years of the N2 gateway project in Cape Town. In Transformation, 76, 22-43.

Millstein, M. (2014). Information and the mediations of power in Delft, Cape Town. In the Nordic Journal for African Studies, 23(2), 100-119.

Millstein, M. (2017). Rights, identities and belonging: reflections on the everyday politics of urban citizenship in Cape Town. Norsk Geografisk Tidsskrift, 71(4), 253-267.

Miraftab, F., \& Wills, S. (2005). Insurgency and spaces of active citizenship: the story of Western Cape AntiEviction Campaign in South Africa. Journal of Planning Education and Research, 25, 200-217.

Parnell, S. (2008). Urban governance in the South: the politics of rights and development. In K. R. Cox, M. Low, \& J. Robinson (Eds.), The SAGE handbook of political geography. London: Sage Publications Ltd.

Republic of South Africa. (1996). Constitution of the Republic of South Africa. Government Gazette. Pretoria: Republic of South Africa.

Robins, S., Cornwall, A., \& von Lieres, B. (2008). Rethinking 'citizenship' in the postcolony. Third World Quarterly, 29, 1069-1086.

Rodgers, D. (2019). Foreword: towards an infrastructural imaginary of the political. In C. Lemanski (Ed.), Citizenship and infrastructure. Practices and identities of citizens and the state (pp unknown). London: Routledge (Routledge Studies in Urbanism and the City).

Roy, A. (2009). Civic governmentality: the politics of inclusion in Beirut and Mumbai. Antipode, 41, 159179.

Shisaka Development Management Services. (2011). Investigation into the delays in issuing title deeds to beneficiaries of housing projects funded by the capital subsidy. Johannesburg: Urban Landmark

Simone, A., \& Pieterse, E. (2017). New urban worlds. Inhabiting dissonant times. Cambridge: Policy Press.

Staeheli, L. A., Ehrkamp, P., Leitner, H., \& Nagel, C. R. (2012). Dreaming the ordinary: daily life and the complex geographies of citizenship. Progress in Human Geography, 36, 628-644.

Tissington, K. (2011). A resource guide to housing in South Africa 1994-2010. Legislation, policy, programmes and practice. Johannesburg: Socio-economic rights institute of South Africa (SERI).

von Schnitzler, A. (2016). Democracy's infrastructure: Techno-politics and protest after apartheid. Princeton (NJ): Princeton University Press.

Wafer, A. (2012). Discourses of infrastructure and citizenship in post-apartheid Soweto. Urban Forum, 23, 233-243. https://doi.org/10.1007/s12132-012-9146-0.

Wafer, A. (2020). Infrastructure in South African cities. In R. Massey \& A. Gunter (Eds.), Urban geography in South Africa. Cham: GeoJournal Library. Springer.

Yiftachel, O. (2009). Theoretical notes on 'grey cities': the coming of urban apartheid? Planning Theory, 8, 87-99.

Publisher's Note Springer Nature remains neutral with regard to jurisdictional claims in published maps and institutional affiliations. 